\title{
KEWARISAN ISLAM DALAM PERSFEKTIF KEADILAN GENDER
}

\author{
Syaikhu \\ IAIN Palngka Raya, Palangka Raya, Indonesia \\ syaikhu@gmail.com
}

Received:27-11-2018; Revised:15-12-2018; Accepted: 17-12-2018

\begin{abstract}
The development of a significant Islamic economy in Indonesia, demands a set of legislations that can provide legal certainty to practitioners of Islamic economics in carrying out sharia economics. The existence of sharia economic regulation in the Indonesian legal system is colored by legal dynamics. This study examines the background of structuring the regulation of Islamic economics in Indonesia, and the dynamics of structuring the regulation of Islamic economics in Indonesia. The method used in this study uses normative legal research with statute approach, historical approach and conceptual approach that is analyzed qualitatively. The results of this study indicate that the needs of the Islamic community in carrying out the part of Islamic Shari'a in the context of Islamic economics muamalah, require compulsory legal certainty in order to provide assurance and assurance of compliance and fulfillment of sharia compliance that must be fulfilled by the state through regulation. The dynamics of structuring sharia economic regulation in Indonesia can be seen in the form of closed systems and open systems, both from operational regulations, institutions and dispute resolution. The dynamics of structuring Islamic economic regulation in a closed system refers to the legal hierarchy and legal system through legal politics that undergo a long process from 1992 to 2018. While in an open system, the dynamics of regulation of sharia economic regulation develops rapidly, responsively and progressively through jurisprudence decisions court and MUI DSN fatwa.
\end{abstract}

Key Words:Dynamics, Arrangement, Regulation, Sharia Economy

ABSTRAK

Hukum sebagai kontrusksi sosial, mempunyai lingkup yang sangat luas, meliputi segala aspek kehidupan manusia.Pandangan klasik mengemukakan bahwa hukum itu netral adanya.Dengan demikian hukum bersifat otonom dan tidak terkait dengan pengaruh-pengaruh di luar bidang hukum.Demikian juga degan pandangan pengertian dalam hukum murni dari Hans Kelsen bahwa hukum itu hanya melihat kebenaran formal, yaitu kebenaran yang tidak melihat kenyataan sosial yang ada.Sehingga hukum ini dikatakana adil apabila mampu berfungsi netral.Tetapi ada yang berpendapat berbeda dengan pandangan diatas bahwa hukum itu dapat dikatakan adil apabila hukum itu melihat kenyataan sosial.Sehingga hukum itu tidak bisa lepas dari pengaruh-pengaruh di luar hukum sehingga hukum tidak bersifat netral namun sangat terkait dengan perilaku dan budaya dalam masyarakat.Dalam membicarakan keadilan dan kesetaraan gender, nampaknya pandangan pertama (positivisme hukum) sudah tidak dapat diterima. Karena hukum positip hanya mengejar kebenaran formal yang sudah baku saja tanpa melihat kenyataan yang di inginkan oleh masyarakat. Nilai-nilai keadilan menurut hukum waris Islam kini tela pula mengalami pergeseran nilai. Oleh karena ini dalam pembagian warisan menurut hukum waris Islam dituntut pula untuk memperhatikan hak laki-laki maupun hak perempuan yang sama 
kuatnya. Persamaan hak antara laki-laki dengan perempuan telah memunculkan isu hangat dalam bias gender yang mengedepankan keadilan berdasarkan akan hak dan kewajiban. Apabila kewajibannya berubah maka haknya pun sudah barang tentu berubah pula.Menyesuaikan dengan perkembangan struktur dalam masyarakat.Karena bagaimanapun masyarakatlah yang menjadi subyek dalam hukum.

Kata Kunci:Waris Islam, Keadilan Gender.

\section{A. Pendahuluan}

Warisan merupakan salah satu ajaran atau syari'at Islam yang sangat penting, bahkan alQur'an pun mengatur dengan sedemikian rupa dalam masalah warisan, baik itu mengenai rukun waris, syarat, maupun pembagian harta warisan. Pembagian harta warisan antara laki-laki dan perempuan yang terlihat lebih mengunggulkan salah satu menimbulkan suatu perselisihan, terutama dalam kondisi sosial pada saat ini di mana hukum waris islam yang membedakan porsi untuk anak laki-laki dan perempuan dianggap oleh sebagian masyarakat tidak lagi relevan untuk diaplikasikan.

Secara sosiologis,menurutSatjiptoRahardjo perubahan sosial merupakan ciri yang melekat dalam masyarakat. Hal ini disebabkan karena masyarakat itu mengalami suatu perkembangan. ${ }^{1}$ Oleh karena itu hukum Islam sebagai salah satu pranata sosial memiliki dua fungsi, fungsi pertama sebagai kontrol sosial yaitu hukum Islam diletakkan sebagai hukum Tuhan yang selain sebagai kontrol sosial sekaligus sebagai socialengineeringterhadap keberadaan suatu komunitas masyarakat. Sedang kontrol yang kedua adalah sebagai nilai dalam proses perubahan sosial yaitu hukum lebih merupakan produk sejarah yang dalam batas-batas tertentu diletakkan sebagai justifikasi terhadap tuntutan perubahan sosial, budaya,dan politik. ${ }^{2}$ Sehingga dalam kontek ini hukum Islam dituntut untuk akomodatif terhadap persoalan umat tanpa harus kehilangan prinsip-prinsip dasarnya. ${ }^{3}$

Dinamika hukum Islam terbentuk oleh interaksi antara wahyu dengan rasio.Kombinasi dua paradigma di ataslah yang mendorong berkembangnya tradisi ijtiijad.Dalam sejarah perkembangan hukum Islam terdapat dua aliran yang besar diantara para pendiri madhzab.Madzhab pertama adalah yangdikenal dengan al Ra'yu( yaitumadzhap yang mengedepankan rasio sebagaipanglima dalam memahami al-Qur'an), sedangkan madzhab yang keduaadalahal-Haditsyaitu (mereka yang mengedepankanHadis Dalam Memahamial-Qur'an) yaitu kelompok yang mempertahankan idealitaswahyu tanpa adanya pemikiran rasional. Pemahaman yang tidak proporsional dalam memandang hukum Islam tersebut misalnya yang dipahami hanya fikihsaja,maka kesan yang akan diperoleh adalah hukum Islam mengalami stagnasi atau jumud dan tidak memiliki kesangupan untuk menjawap tantangan zaman.

Hukum Islam mempunyai dinamika dan karakter sendiri serta mempunyai ruang lingkupnya sendiri.Sistem hukum Islam mempunyai system yang tersendiri yang dikenal dengan hukum fikih.Hukum fikih bukanlah hukum yang sempit tetapi hukum yang masih sangat luas.Hukum fikih ini mencakup semua aspek kehidupan umat manusia.Baik yang bersifat ibadah maupun muamalah.Ibadah adalah hukum mengenai bagaimana manusia berhubungan dengan

\footnotetext{
${ }^{1}$ Artijo Alkostar, M Sholeh Amin, Pembangunan Hukum Dalam Perspektif Politik Hukum Nasional, Rajawali Pers, Jakarta, 1986, hlm. 35

${ }^{2}$ Qurtubi Al Sumanto ,Era baru Figih Indonesia hlm 5 Yogyakarta Cermin 1999

${ }^{3}$ Ahmad Rofiq, Pembaharuan Hukum Islam di Indonesia, Gama Media, Yogyakarta, 2001, Hlm. 98
} 
Allah, sedang muamalah adalah hukum yang mengatur berbagai hubungan antar sesama manusia.

Hukum Islam dirumuskan sebagai sekumpulan aturan keagamaan yang mengatur perilaku kehidupan manusia dengan segala aspeknya. Baik yang bersifat pribadi maupun kelompok. Karena sifatnya yang serba mencakup inilah yang menempatkan agama Islam dalam tatanan kehidupan umat manusia yang belum pernah dicapai oleh agama atau kepercayaan lain sebelum Islam. Dengan demikian akan sangat sulit memahami Islam tanpa memahami hukum Islam dengan sepenuhnya. ${ }^{4}$

Asas hukum dalam pewarisan Islam tidak memandang perbedaan antara aki-laki dengan perempuan semua ahli waris baik laki-laki maupun perempuan mempunyai hak yang sama sebagai ahli waris. Tetapi hanyalah perbandinganya saja yang berbeda. Memang didalam hukum waris Islam yang ditekankan keadilan yang berimbang dipakai, bukanlah keadilan yang sama rata sebagai sesama ahli waris. Karena prinsip inilah yang sering menjadi polemic dan perdebatan yang kadang kala menimbulkan persengketaan diantara para ahli waris. Begitu pula gerakan wanita yang memperjuangkan haknya untuk setara dengan kaum laki-laki. Karena di zaman sekarang peran perempuan danperan laki-laki hampir sama dalam menjalamkan roda perekonomian keluarga. Perempuan yang dahulu hanya dikotomikan hanya bertugas dalam urusan rumah tangga telah mengalami pergeseran nilai seiring dengan perubahan zaman.

Dengan majunya kapitalisme telah membuka kesempatan baru bagi perempuan termasuk kemungkinan untuk eksis di luar keluarga dan menentang dominasi laki-laki dengan budaya patriarki. Pembagian kerja berdasarkan jenis kelamin laki-laki menjadi kontrol kemampuan produksi. Kesetaraan penuh antara laki-laki dan perempuan akan tercapai penuh melalui tercapainya kemajuan teknologi dimana pekerjaan tidak harus mengunakan tenaga yang besar tetapi dapat dilaksanakan dengan kemampuan ilmu dan ketrampilan. ${ }^{5}$

Kapitalisme industri telah menghancurkan unit kerja suami dan istri,awalnya perempuan setidaknya telah menjadi lebih tergantung kepada laki -laki bagi keberlangsungan ekonominya. Kapitalisme dan patriarki merupakan dua sistem yang saling berkaitan.Karenanya, ada hubungan antara pembagian kerja dan upah dan kerja domestik, pembagian kerja domestik yang hirarkis terus dihidupkan oleh keluarga telah mengenyampingkan peranan produktif tradisional bagi keberlangsungan dan kebaikan dalam masyarakat.Yang dahulu wanita hanya sebagai pendamping pria dalam mencari nafkah kini telah mengalami pergeseran.Kini perempuan tidak sedikit alah menjadi tulang punggung perekonomian keluarga.Perubahan inilah yang menjadikan perubahan sosial yang dahulu wanita merupakan sebagai mahluk kelas dua kini telah mensejajarkankedudukanya dengan laki -laki begitu pula dalam tuntutan dalam pembagian terhadap harta warisan. Sebab didalam istem hukum kewarisan Islam menempatkan pembagian yang tidak sama antara laki-laki dengan perempuan.

Seiring dengan bias Gender kaum feminis selalu meminta kedudukan yang sama dengan laki -laki, sebab pada prinsipnya hukum tidak membedabedakan jenis kelamin antara laki-laki dengan perempuan. Semakin banyaknya tuntutan kaum feminis terhadap kaum maskulin mempengaruhi pula terhadap system hukum yang berlaku dalam masyarakat. Arti keadilanpun mengalami perubahan yang sangat berarti yang dahulu laki-laki merupakan sebagi orang yang

\footnotetext{
${ }^{4}$ Taufik Adnan Amal, Islam dan Tantangan Moderenitas, Mizan, Bandung, 1994, Hlm. 33

${ }^{5}$ Fakih Mansor, Analisis Gender dan Tranformasi Sosial, Pustaka Pelajar, Yogyakarta, 1999, Hlm. 50
} 
bertanggung jawab terhadap setiap permasalahan dalam rumah tangga tetapi sekarang telah mengalami perubahan yang berarti. ${ }^{6}$

Pergeseran peran laki-laki dan perempuan inilah yang menjadi isu Gender di masyarakat tuntutan kaum perempuan terhadap hak-haknya sesuai peran perempuan dalam keluarga.Sehingga hukum waris Islam pun harus dapat pula mengakomodir kebutuhan masyarakat terhadap hukum yang dapat memberikan keadilan terhadap perempuan dimasa sekarang ini. Dimana terjadi perbedaan perhitungan pembagian dalam hukum waris Islam, yakni laki -laki mendapat bagian yang lebih banyak dari perempuan.

Gender adalah salah satu isu sentral dalam kajian hukum Islam dewasa ini. Oleh sebab itu, mesti dipahami bahwa ketika membicarakan sesuatu dalam konteks hukum Islam akan sangat erat kaitannya dengan syari'ah dan fiqih.

Asas hukum dalam pewarisan Islam tidak memandang perbedaan antara laki- laki dengan perempuan, semua ahli waris baik laki-laki maupun perempuan mempunyai hak yang sama sebagai ahli waris. Tetapi hanyalah perbandingannya saja yang berbeda. Memang di dalam hukum waris Islam yang ditekankan adalah keadilan yang berimbang, bukanlah keadilan yang sama rata sebagai sesama ahli waris. Karena prinsip inilah yang sering menjadi polemik dan perdebatan yang kadang kala menimbulkan persengketaan diantara para ahli waris.

\section{B. Metode Penelitian}

Penelitian ini merupakan penelitian hukum normatif dianalisis dengan pendekatan perundang-undangan (statute approach),pendekatan sejarah (historical approach) dan pendekatan konseptual (conceptual approach). ${ }^{7}$ Penelitian hukum normatif menggunakan bahanbahan hukum berupa peraturan perundangan, seperti Undang-undang, hingga Peraturan Pemerintah. Peraturan mengenai Kewarisan Islam dalam Persfektif Gender ini juga menggunakan sumber-sumber Hukum Islam. Dalam penelitian ini seorang peneliti selalu mendasarkan pemikirannya pada aturan perundangan sebagai bahan hukum utama penelitian. Penelitian atas bahan-bahan hukum seperti perundang-undangan dan putusan pengadilan tidak dapat dikategorikan sebagai sebuah penelitian sosial, mengingat ia memisahkan hukum dari segala bentuk analisis non hukum.Bahanhokumnormatif yang dijadikan sebagai rujukan dalam penelitian ini terbagi kepada tiga bahan, yakni bahan primer, sekunder dan tersier.Bahan primer meliputi Undang-Undang Selain sumber primer tersebut, sebagai bahan pendukung digunakan pula sumber sekunder dan tersier.Sumber sekunder yaitu karya-karya atau teori-teori yang membahas sumber primer, seperti, peraturan perundang-undangan terkait, serta pemikiran para pakar. Adapun sumber tersier yaitu hal-hal yang mendukung sumber primer dan sekunder seperti, kamusdan sebagainya

\section{Pembahasan.}

\section{Asas-asas Hukum Kewarisan Islam}

\footnotetext{
${ }^{6}$ Bambang Sugiharto, Post Modern Tantangan Bagi Filsafat, Kanisius, Yogyakarta, 1996, Hlm. 100

${ }^{7}$ Penelitian hukum dalam level dogmatik hukum atau penelitian hukum untuk keperluan praktik hukum tidak dapat melepaskan diri dari pendekatan perundang-undangan, pendekatan sejarah, dan pendekatan konseptual. Lihat Peter Mahmud Marzuki, Penelitian Hukum, Jakarta: Kencana, 2010, h. 94.
} 
Adapun yang menyangkut asas-asas hukum kewarisan Islam dapat digali dari ayat-ayat hukum kewarisan serta sunnah Nabi Muhammad SAW. Asas-asas dapat diklasifikasikan sebagai berikut $:^{8}$

1. Asasljbari

Secara etimologi "Ijbari" mengandung arti paksaan, yaitu melakukan sesuatu di luar kehendak sendiri. Dalam hal hukum waris berarti terjadinya peralihan harta seseorang yang telah meninggal kepada yang masih hidup terjadi dengan sendirinya. Artinya tanpa adanya perbuatan hukum atau pernyataan kehendak dari pewaris. Dengan perkataan lain adanya kematian pewaris secara otomatis hartanya beralih kepada ahli warisnya. AsasIjbari ini dapat dilihat dari berbagai segi yaitu: 1. Dari peralihan harta; 2. dari segi jumlah harta yang beralih; 3 dari segi kepada siapa harta itu akan beralih. Ketentuan asasIjbari ini dapat dilihat antara lain dalam ketentuan Al-Qur'an, surat An-Nisa ayat 7 yang menyelaskan bahwa: bagi seorang laki-laki maupun perempuan ada nasib dari harta peninggalan orang tuanya atau dari karib kerabatnya, kata nasib dalam ayat tersebut dalam arti saham, bagian atau jatah dari harta peninggalan sipewaris.

2. Asas Bilateral

Adapn yang dimaksud dengan asas bilateral dalam hukum kewarisan Islam adalah seseorang menerima hak kewarisan bersumber dari kedua belah pihak kerabat, yaitu dari garis keturunan perempuan maupun keturunan laki-laki. Asas bilateral ini secara tegas dapat ditemui dalam ketentuan Al-Qur'an surat An-Nisa ayat 7, 11, 12 dan 176, antara lain dalam ayat 7 dikemukakan bahwa seorang laki-laki berhak memperoleh warisan dari pihak ayahnya maupun ibunya. Begitu juga dengan perempuan mendapat warisan dari kedua belah pihak orang tuanya. Asas bilateral ini juga berlaku pula untuk kerabat garis ke samping (yaitu melalui ayah dan ibu).

3. Asas Individual

Pengertian asas individual ini adalah: setiap ahli waris (secara individu) berhak atas bagian yang didapatkan tanpa terikat kepada ahli waris lainya. Dengan demikian bagian yang diperoleh oleh ahli waris secara individu berhak mendapatkan semua harta yang telah menjadi bagiannya. Ketentuan ini dapat dijumpai dalam ketentuan Al-Qur'an surat An-Nisa ayat 7 yang mengemukakan bahwa bagian masing-masing ahli waris ditentukan secara individu.

4. Asas Keadilan Berimbang

Asas keadilan berimbang maksudnya adalah keseimbangan antara hak dengan kewajiban dan keseimbangan antara yang diperoleh dengan kebutuhan dan kegunaan. Dengan perkataan lain dapat dikemukakan bahwa faktor jenis kelamin tidak menentukan dalam hak kewarisan. Dasar hukum asas ini adalah dalam ketentuan Al-Qur'an surat An-Nisa ayat 7, 11, 12 dan 179

\section{Pemikiran tentang Keadilan}

Pemahaman tentang keadilan itu sendiri tergantung dari tuntutan manusia pada zamannya sendiri. Keadilan memang tidak dapat dipisahkan dari persoalah hukum dan persoalan manusia karena manusialah yang selalu menjadi subyek dari segala hukum. Karena

\footnotetext{
${ }^{8}$ Suhardi K Lubis, Komis Simanjuntak, Hukum Waris Islam Lengkap dan Praktis, Sinar Grafika, Jakarta, 1995, Hlm. 37
} 
manusialah yang mempunyai kesadaran dalam melakukan perbuatan hukum baik yang baik maupun yang tidak baik, adil maupun yang tidak adil, indah dan buruk. ${ }^{9}$

Kesadaran akan keadilan dalam diri manusia biasanya akan timbul dan tenggelam dalam batin manusia. Timbulnya keadilan dalam masyarakat berarti timbul kesadaran akan makna tatanan kehidupan dalam masyarakat baik secara individu maupun secara komunal.

Menurut John Rawl bahwa masyarakat dapat dikatakan baik apabila didasarkan pada dua prinsip, yaitu fairnees, yang menjamin bagi setiap anggota masyarakat terhadap nilai-nilai kebebasan semaksimal mungkin dan veilignorance, yang hanya membenarkan ketidaksamaansosial maupun ekonomi dan apabila ketidaksamaan itu dilihat dalam jangka panjang akan menguntungkan bagi mereka yang kurang beruntung. ${ }^{10}$

Di dalam pandangan ini seakan disetujui sebuah formasi tatanan masyarakat yang netral, yang tidak mendahulukan harapan-harapan lain yang ada dalam masyarakat. Secara umum utilitiarismemengajarkan bahwa benar dan salahnya manusia terhadap peraturan tergantung pada konsekuensi langsung dari peraturan atau tindakan tertentu yang dilakukan. Dengan demikian, baik buruknya tindakan manusia secara moral sangat tergantung dari konsekuensi tindakan tersebut, apabila akibatnya baik maka hukum itu baik tetapi sebaliknya apabila akibatnya buruk maka hukum itu juga buruk. ${ }^{11}$

Bertolak dari itu dapat dibangun teori tentang keadilan yang mampu untuk menegakkan keadilan bersama sekaligus dapat dipertanggungjawabkan secara obyektif, khususnya dalam kacamata demokrasi. Teori keadilan dapat dibangun dan dapat memadai untuk menjawab persoalan apabila dibentuk dengan pendekatan kesepakatan bersama. Dimana prinsip-prinsip keadilan yang dipilih dipegang dan disepakati bersama dengan rasional. Yang disebut Rawls dengan Justice as Fairness. Penerapan yang konsisten dalam hukum sedikitnya dapat membantu anggota masyarakat dari hal-hal apa boleh dilakukan atau yang tidak boleh dilakukan olehnya. Sehingga dengan konsep ini menurut Rawl keadilan formal adalah keadilan yang dipaksakan oleh pihak penguasa untuk mencapai suatu tujuan yang tidak bebas nilai. Sedangkan hukum yang mencerminkan keadilan, apabila hukum itu dapat diterima oleh semua pihak dan tidak memihak kepada siapapun, baik kepada penguasa maupun kepada yang dikuasai.

Dalam pandangan Islam, tujuan akhir hukum adalah keadilan. Kaitannya dengan hukum Islam, keadilan harus dicapai meski mengacu pada pokok agama Islam, yaitu Al-Qur'an dan Hadis. Arti dari tujuan keadilan melalui jalur hukum yang harus berawal dari dua segi dan mengarah pada keadilan dua segi juga. Khususnya yang berkaitan dengan hukum agar manpu tampil sesuai dengan prinsip keadilan secara umum. Perpaduan mencari keadilan menjadi standar hukum universal yang mampu tampil dimanapun dan kapanpun sesuai dengan fitrahditurunkannya Islam ke muka bumi. ${ }^{12}$

Keadilan bagi manusia mengarah pada berbagai definisi keadilan yang tidak bukan mungkin antara satu masyarakat manusia dengan yang lainnya berbeda dalam mengartikan keadilan hukum. Artinya fleksibilitas produk keadilan mutlak perlu diperlakukan dalam

\footnotetext{
${ }^{9}$ Notohamijojo, Masalah :Keadilan, Hakikat dan Pengenaannya dalam Bidang Masyarakat, Kebudayaan, Negara dan Antar Negara, Tirta Amerta, Semarang, 1971, Hlm. 21

${ }^{10}$ Aristoteles, "The Ethics Of Aristoteles" Dalam S Tasrif,Bunga Rampai Filsafat Hukum, Abardin, Jakarta, 1987, Hlm. 98

${ }^{11}$ Andre Ata Ulan, Keadilan dan Demokrasi, Telaah Filsafat Politik John Rowls, Kanisius, Yogyakarta, 2001, Hlm. 21

${ }^{12}$ Abdul Ghofur Anshari, Filsafat Hukum Kewarisan Islam, UII Press, Yogyakarta, 2005, Hlm. 153
} 
heterogenitas manusia dan lingkungannya, sedangkan muara keadilan adalah kepada Allah. Hukum Allah adalah produk hukum yang tetap menempatkan Allah sesuai dengan proporsinya sehingga perbuatan manusia harus tetap dalam koridor hukum Allah.

Selanjutnya dalam keadilan pandangan masyarakat hukum adat sangat sukar berfikir secara rasional tetapi lebih dipengaruhi oleh pola pikir yang komunal magis-religius. Alam pikiran ini menempatkan kehidupan manusia merupakan bagian yang tidak dapat terpisahkan dari alam. Kehidupan manusia taut menaut dengan keadaan alam, apabila alam mengalami kegoncangan berarti manusia melakukan perbuatan yang melanggar ketentuan hukum alam.

Hukum adat sebagaimana dikemukakan oleh Holleman, hukum adat mempunyai empat ciri umum yang dipandang sebagai dari satu kesatuan yang tidak dapat dipisahkan. Adapun empat ciri tersebut adalah pertama religius magis, yaitu perpaduan pikiran yang mengandung logika animisme yaitu pandangan yang berhubungan dengan alam gaib. Keduaadalah komunal yaitu sifat yang mementingkan kepentingan bersama daripada kepentingan pribadi. Sifat yangketiga adalah tunai, yaitu kebiasaan dalam masyarakat dalam jual beli bersifat tunai yaitu hak dan kewajiban dilakukan dalam waktu yang sama. Yang keempat adalah konkrit, yaitu dalam melakukan perbuatan harus bersifat nyata. ${ }^{13}$

Sejak negara Indonesia merdeka pembuat undang-undang sudah menyetujui prinsip kesetaraan antara laki-laki dengan perempuan hal ini terbukti dalam rumusan Undang-undang dasar 1945, sebagai mana dinyatakan dengan dengan tegas dalam pasalk 27 ayat (1), juga dalam Undang-undang perkawinan. Telah menjadi hukum positip di Indonesia yang mengandung penghapusan diskriminasi terhadap perempuan.Bahwa perempuan adalah haknya sejajar dengan laki-laki agar tercapai rasa keadilan untuk semua pihak.Salah satu cirri hukum modern adalah pengunaan secara sadar terhadap hukum yang berlaku tanpa adanya paksaan dari pihak manapun. Hukum tidak hanya dipakai dipakai untuk menguatkan pola kebiasaan dalam masyarakat, melainkan hukum diarahkan untuk tujuan tujuan yang dikehendaki, penghapusan kebiasaan yang dipandang tidak sesuai maka akan diganti dengan pola prilaku baru yang dikehendaki. Hukum sebagai kontrusksi sosial, mempunyai lingkup yang sangat luas, meliputi segala aspek kehidupan manusia.Yang menimbulkan pola pengertian yang berbeda terhadap pengertian hukum.

Pandangan klasik mengemukakan bahwa hukum itu netral adanya.Dengan demikian hukum bersifat otonom dan tidak terkait dengan pengaruh-pengaruh di luar bidang hukum.Demikian juga dengan pandangan pengertian dalam huikum murni dari Hans Kelsen bahwa hukum itu hanya melihat kebenaran formal, yaitu kebenaran yang tidak melihat kenyataan social yang ada.Sehingga hukum ini dikatakana adil apabila mampu berfungsi netral.Tetapi ada yang berpendapat berbeda dengan pandangan diatas bahwa hukum itu dapat dikatakan adil apabila hukum itu melihat kenyataan sosial.Sehingga hukum itu tidak bisa lepas dari pengaruhpengaruh di luar hukum sehingga hukum tidak bersifat netral namun sangat terkait dengan perilaku dan budaya dalam masyarakat.Dalam membicarakan keadilan dan kesetaraan jender, nampaknya pandangan pertama (positivisme hukum) sudah tidak dapat diterima. Karena hukum positip hanya mengejar kebenaran formal yang sudah baku saja tanpa melihat kenyataan yang di inginkan oleh masyarakat.

Kemajuan-kemajuan yang telah dicapai oleh bidang ilmu-ilmu sosial member pengaruh pandangan, pengaruh sarjana hukum terutama yang berpandangan hukum bukan hanya dilihat

\footnotetext{
${ }^{13}$ Imam Sudiyat , Asas-Asas Hukum Adat, Bekal Pengantar, Liberty, Yogyakarta, 1982, Hlm. 30-31
} 
dari legitimasiny, melainkan hukum dipandang juga dari segi efektivitasnya. Hukum tidak hanya mengatur dalam prosedur hukum saja tetapi tetapi hukum melihat apa yang dikehendaki oleh masyarakatnya. Hal yang terpenting dalam hukum yang terpenting adalah bagaimana hukum itu dilaksanakan di dalam masyarakat.Hukum dibuat untuk kepentigan masyarakat apabila hukum itu tidak dilaksanakan oleh masyarakat lagi maka hukum tersebut tidak dapat dikatakan hukum lagi.

Hukum yang adil adalah hukum yang dapat dilaksanakan oleh masyarakat. Tetapi konsep mengenai keadilan oleh sebagian masyarakat masih jauh panggangan dari api yang artinya hukum itu tidak sesuai dengan apa yang diinginkan. Sehingga muncul berbagai makna tentang keadilan. Makna keadilan merupakan pandangan yang relative .pada sisi yang lain keadilan adalah merupakan hasil hubungan antara harapan dengan kenyataan. Dari aspek tata bahasa kata adil dari bahasa Arab adalayang mengandung arti tengah-tengah.Dari pengertian inilah kata adil adalah orang yang sangup berdiri di tengah tapa harus berpihak kepada salah satu pihak. Orang yang demikian adalah orang yang selalu menyadari setiap persoalan yang dihadapinya.sehingga setiap keputusan yang diambilnyaakan menjadi benar pula.

Sementara itu, menurut Murtadha al Mutthahari ada beberapa pengertian pokok tentang keadilan, diantaranya keadilan mengandung makna pertimbangan atau keadaan setimbang dan tidak ada diskriminasi dalam bentuk apapun.Keadilan haruslah memperhatikan hak-hak pribadi atau golongan dengan memberikan hak itu kepada yang berhak sedang loawan dari keadilan adalah kezaliman yaitu keadaan dimana tidak menempatkan hak pada mestinya.Dalam memahami keadilan juga dapat dengan lawan katanya yaitu ketidak adilan. Dalam bahasa Arab “ Ketidakadilan" dikenal dengan istilah zalim yang dapat digunakan pengertian kesalahan. Dengan demikian keadilan mengandung arti kebaikan yang tidak mengandung pelanggaran dan berusaha menempatkan sesuatu ' pada teeempatnya berdasarkan norma-norma yang baik dan buruk berdasar kan pada wahyu Tuhan dan prinsip-prinsip hukum yang bersifat dasar. ${ }^{14}$

Kewarisan bilateral dalam hukum Islam mengandung dua nilai keadilan, yaitu keadilan Tuhan dan keadilan manusia. Keadilan Tuhan adalah nilai keadilan yang mendasarkan pada pengertian bahwa keadilan yang berasal dari yang transendental. Artinya keadilan dapat tercapai apabila melalui penempatan Tuhan secara proporsional. Dalam pengertian ini Tuhan adalah titik sentral setiap gerak dan tingkah laku mahluk dari awal kejadian sampai peraturan yang menjadi standar tingkah laku makluk. Sedangkan keadilan manusia adalah keadilan yang mendasarkan prinsip-prinsip pada nilai keadilan manusiawi.

Hukum kewarisan Islam hasil ijtihadSyafi'i oleh sebagian besar umat Islam telah dijadikan sebagai sumber hukum normatif dan harus diterima sebagai hukum yang mengikat dan terpancar dari perintah Allah dalam Al-Qur'an dan Hadis, sehingga layak bagi setiap muslim untuk merasakan tidak adil terhadap hukum kewarisan tersebut. Pemahaman semacam ini pada awalnya dianggap sebagai prinsip keadilan obyektif semata keluar dari penilaian keadilan subyektif, terutama bagi masyarakat dengan sistem kekeluargaan matrilineal dan bilateral sebab kewarisan Syafi'ibercorakpatrilinial. Akan tetapi seiring dengan perjalanan waktu penilaian keadilan subyektif beradaptasi dengan penilaian keadilan obyektif sebagai warisan sesuai dengan keadilan dua segi sekaligus, yaitu keadilan obyektif dan keadilan subyektif.

$\underline{\text { Keadilan Gender }}$

\footnotetext{
${ }^{14}$ Nurcholis Madjid Islam kemanusiaan dan kemoderenan, Doktrin dan Peradaban, sebuahTelaah Kritis Tentang Masalah Keimaanan, ( Jakarta yayasan Wakaf, Cetakan Ke 2,1992 ) h. 513-516
} 
Syari'at Islam tidak membedakan manusia atas dasar jenis kelamin. Perbedaan peran dan fungsi tidak berarti terjadinya diskriminasi atau degradasi satu sama lain. Manusia memiliki hakhak umum untuk hidup dalam martabat, hak untuk memiliki bekal hidup dan hak-hak sosial dan sipil.

Gender menurut hukum Islam diletakkan dalam proporsi yang semestinya, karena gender dalam pengertian jenis kelamin, merupakan fitrah ciptaan Allah dan diatur berdasarkan ketentuan Allah.Karena itu, laki-laki dan perempuan dapat berkiprah sesuai dengan fitrahnya yang mestinya tidak dibatasi oleh aturan hukum buatan manusia. Kalau ada kalangan yang berpandangan, ayat Al-Qur'an dan sunnahshahihah bias gender, yang menjadi masalah bukanlah ayat dan sunnahnya, akan tetapi pandangan yang dimunculkan oleh kalangan tersebutlah inti permasalahannya. Oleh sebab itu, memunculkan aturan hukum buatan manusia yang berspektif gender sangat memungkinkan sepanjang tidak melanggar rambu-rambu yang telah ditetapkan oleh syari'at Islam.

Konsep kewarisan bilateral adalahmawali. Konsep ini dipandang memenuhi standar keadilan gender. Mawali disebut sebagai pengurangan dominasi laki-laki dalam hukum kewarisan Islam sebelumnya. Dalam kewarisan Syafi'i, anak perempuan menjadi asabah bukan atas kedudukan sendiri sebagai asabah tetapi disebabkan adanya anak laki-laki yang menariknya sebagai asabah, dalam bahasa Syafi'i disebut asabahbi alghairi. Konsep kewarisan model Syafi'i tersebut bertolak belakang dengan konsep yang ditawarkan Hazairin, dalam konsep Hazairin anak laki-laki dan perempuan mempunyai hak dan kedudukan yang sama sebagai ahli waris, keduanya berdiri sendiri tanpa adanya ketergantungan antara satu dengan yang lainnya. Konsep mawali bila dibandingkan dengan prinsip NaminemLaederenyaSoekanto akan menampakkan keserasian. Sebab mawali menjadikan cucu sebagai ash-habulfaraidl, padakewarisan Syafi'i yang dirugikan oleh saudara pewaris menjadi ahli waris yang mendapatkan bagian menggantikan kedudukan ayah atau ibunya.

Demikian pula dengan prinsip SuumCuiqueTribuere. Bila anak laki-laki mempunyai kemampuan menghijab, maka berikanlah hak yang sama bagi anak perempuan. Hal ini sesuai dengan penggantian SuumCuiqueTribuereyaitu "apa yang anda boleh mendapatkannya". Begitu juga dalam Al-Qur'an, Allah tidak pernah membedakan laki-laki dengan perempuan.

Di samping itu konsep kewarisan Syafi'i yang dinilai bias gender adalah perbedaan kemampuan menghijab antara laki-laki dengan perempuan. Anak laki-laki dapat menghijab para saudara dari segala jurusan, baik laki-laki maupun perempuan, kakek dan nenek dari pewaris mempunyai kemampuan untuk itu. Sedangkan dalam konsep kewarisan bilateral, anak laki-laki dan perempuan mempunyai kemampuan yang sama dalam urusan hajib-mahjub. Anehnya, bagi sebagian orang bentuk ketidaksetaraan laki-laki dengan perempuan dianggap sebagai sesuatu yang adil. Hal ini bukan saja ada dalam kewarisan Islam, bahkan beberapa peneliti ada yang menganggap hal itu sebagai bentuk keadilan. Crosby (1982), Feather (1990), Jacson dkk (1992) menemukan bahwa perempuan lebih mudah memberikan penilaian terhadap perbedaan derajat tersebut. Hal semacam ini cenderung menjadi false consciousness yang perlu perhatian dan usaha untuk memperbaikinya, sebab Al-Qur'an tidak pernah membedakan jenis kelamin dalam keadilan kewarisan.

\section{Prinsip Keadilan Berimbang dalam Hukum Kewarisan Islam}

Kata adil merupakan bahasa Indonesia yang berasalkan dari kata al-adlu, di dalam AlQur'an kata al-adlu atau turunannya disebut lebih dari 28 (dua puluh delapan) kali. Sebagian diantaranya diturunkan Allah dalam bentuk kalimat perintah dan sebagian dalam bentuk kalimat berita. Kata al-adlu itu dikemukakan dalam konteks yang berbeda dan dalam arah yang 
berbeda pula. Sehingga akam memberikan definisi yang berbeda sesuai dengan konteks tujuan penggunaannya. ${ }^{15}$ Dalam hubungan dengan hak yang menyangkut materi, khususnya yang menyangkut dengan kewarisan kata tersebut dapat diartikan: keseimbangan antara hak dan kewajiban, keseimbangan antara yang diperoleh dengan keperluan dan kegunaan.

Atas dasar pengertian tersebut di atas terlihat jelas asas keadilan dalam pembagian harta warisan dalam hukum Islam. Secara mendasar dapat dikatakan bahwa perbedaan gender tidak menentukan hak kewarisan dalam Islam. Artinya sebagaimana laki-laki dan perempuan mempunyai hak yang sama kuatnya untuk mendapatkan warisan. Hal ini secara jelas disebut dalam Al-Qur'an dalam surat an-Nisa ayat 7 yang menyamakan kedudukan laki-laki dan perempuan dalam hak mendapatkan warisan. Pada ayat 11-12, 176 surat an-Nisa secara rinci diterangkan kesamaan kekuatan hak menerima warisan antara anak laki-laki, dan anak perempuan,

Ayah dan ibu (ayat 11), suami dan istri (ayat 12), saudara laki-laki dan perempuan (ayat 12 dan 176). Tentang jumlah bagian yang didapat oleh laki-laki dan perempuan terdapat dalam dua bentuk. Pertama: laki-laki mendapat jumlah yang sama banyak dengan perempuan; seperti ayah dengan ibu sama-sama mendapatkan seperenam dalam keadaan pewaris meninggalkan anak kandung, sebagaimana yang dinyatakan dalam ayat 11 surat an-Nisa. Begitu pula dengan saudara laki-laki dengan saudara perempuan sama-sama mendapat seperenam. Apabila seorang pewaris tidak memiliki ahli waris langsung seperti suami/istri, anak, bapak dan ibu maka berlaku surat an-Nisa' ayat 12. Kedua: laki-laki memperoleh bagian lebih banyak dua kali lipat dari yang di dapat oleh perempuan yaitu: anak laki-laki dengan anak perempuan, suami dengan isteri, sebagaimana tersebut dalam ayat 12 surat an-Nisa'.

Ditinjau dari segi jumlah bagian saat menerima hak, memang terdapat ketidaksamaan. Akan tetapi hal tersebut bukan berarti tidak adil, karena keadilan dalam pandangan Islam tidak hanya diukur dengan jumlah yang didapat saat menerima hak waris tetapi juga dikaitkan kepada kegunaan dan kebutuhan. Karena secara umum pria membutuhkan lebih banyak materi dibandingkan dengan wanita. Hal tersebut dikarenakan pria dalam ajaran Islam memikul kewajiban ganda yaitu untuk dirinya sendiri dan terhadap keluarganya termasuk para wanita; sebagaimana dijelaskan Allah dalam surat an-Nisa' ayat 34.

Walaupun kerabat garis ke atas, yaitu orang tua dan kerabat garis ke bawah yaitu anak sama-sama berhak atas harta warisan bahkan dalam surat An-Nisa ayat 11 menyatakan bahwa keduanya mempunyai kedudukan yang sama, namun terdapat perbedaan dalam jumlah yang diterima. Anak rata-rata mendapatkan bagian yang lebih besar dibandingkan dengan apa yang diterima oleh orang tuanya. Adanya perbedaan ini dapat dikaji dari segi hak dan kewajiban, serta tanggung jawab, maka tanggung jawab orang tua terhadap anak lebih besar daripada tanggung jawab anak terhadap orang tua.

Hak warisan yang diterima oleh ahli waris pada hakekatnya merupakan kontinuitas tanggung jawab pewaris terhadap keluarganya atau ahli waris berimbang dengan perbedaan tanggung jawab seseorang (yang kemudian menjadi pewaris) terhadap keluarga (yang kemudian menjadi ahli waris) bagi seorang laki-laki tanggung jawab yang utama adalah istri dan anak-anaknya merupakan kewajiban yang harus dipikulnya.

Umur juga tidak menjadi faktor yang menentukan dalam pembagian harta warisan. Dilihat dari segi kebutuhan sesaat yaitu waktu menerima hak, terlihat bahwa kesamaan jumlah penerimaan antara yang besar dengan yang kecil tidaklah adil, tetapi tinjauan dari kebutuhan

\footnotetext{
${ }^{15}$ Amir Syarifuddin, Hukum Kewarisan Islam, Prenada Media, Jakarta, 2004, Hlm. 24-27
} 
tidak bersifat saat dilangsungkannya pembagian harta warisan tetapi untuk jangka waktu yang lama sampai pada usia dewasa, yang kecil membutuhkan materi yang sama banyaknya dengan orang yang sudah dewasa. Bila dihubungkan dengan besarnya keperluan orang dewasa dengan lamanya keperluan bagi anak yang belum dewasa dan dikaitkan pula kepada perolehan yang sama dalam hak kewarisan, maka hasilnya keduanya akan mendapatkan kadar manfaat yang sama atas apa yang mereka terima. Inilah keadilan hakiki dalam pandangan Islam, yaitu keadilan berimbang dan bukan keadilan yang sama rata.

Allah SWT telah menetapkan sesuatu sesuai dengan kehendak-Nya. Ketetapan Allah tersebut dilihat pula dampak negatif serta positif yang akan terjadi, begitupun dengan pembagian warisan. Apabila pembagian harta warisan tidak akan menimbulkan suatu dampak negatif, tentunya pembagian warisan akan diserahkan begitu saja kepada manusia dan Allah SWT tidak akan ikut campur ke dalamnya. ${ }^{16}$

Keadilan dalam pembagian warisan tidak dapat diukur dari besarnya atau sedikitnya harta yang didapatkan, tetapi hal tersebut berdasarkan kebutuhan yang dimilikinya.Sistem yang telah ditetapkan oleh al-Qur'an merupakan aturan yang adil.Hal ini telah diakui oleh seluruh pakar hukum di Eropa.

"Jika dalam pembagian waris para ahli waris menghendaki pembagian yang bukan berdasarkan hukum Islam dengan membagi sama rata dan semua pihak telah menyepakati hal tersebut, maka dibenarkan, selama pembagian secara merata tersebut bukan atas dasar menilai bahwa kadar pembagian yang ditetapkan oleh Allah tidak adil atau keliru"

Keadilan dalam pembagian warisan dengan kadar 2:1 yang terlihat lebih memihak kepada kaum laki-laki karena jumlah harta yang diterima lebih besar, tidak bisa dipandang menjadi sesuatu yang tidak adil hanya karena kadar yang berbeda antara keduanya. Pada hakikatnya keadilan tidaklah harus sama besar dan bernilai sama. Adil berarti seimbang atau sebanding.Perbandingan 2:1 mungkin terlihat tidak adil dan 1:1 yang terlihat lebih adil di mata manusia.Namun belum tentu adil dalam pandangan Allah.Al-Qur'an mengingatkan kepada manusia bahwa sesuatu yang terlihat menyenangkan belum tentu baik, dan sesuatu yang tidak menyenangkan mungkin sebaliknya, yakni sesuatu yang lebih baik yang telah ditentukan oleh Allah.

Dalam Tafsir al-Misbah karya M. QuraishShihab disebutkan pembagian waris antara lakilaki dan perempuan hendaknya berdasarkan al-Qur'an dengan kadar 2:1. Hal ini dengan alasan karena pembagian warisan antara laki-laki dan perempuan merupakan ketetapan dari Allah yang tidak bisa dirubah oleh siapapun dan tidak pula ditentang. Sedangkan MunawirSjadzali menghendaki pembagian warisan antara laki-laki dan perempuan dengan pembagian yang sama besar, yakni dengan kadar 1:1. MunawirSjadzali menghendaki pembagian yang seperti itu karena melihat realitas yang ada dalam masyarakat.

Namun, Allah Maha Mengetahui lagi Maha Bijaksana sampai masalah yang sekecil itu pun diaturnya dengan sedemikian rupa.Sehingga tidaklah mengherankan jika Allah menggunakan hak prerogatif-Nya dalam pembagian harta warisan tanpa ada campur tangan manusia sedikitpun, karena pada hakikatnya manusia memiliki sifat tidak puas dan serakah. Terlebih lagi dalam pembagian warisan para ahli waris lebih mementingkan dirinya sendiri tanpa melihat hakhak orang lain yang ada di sekitarnya.

\footnotetext{
${ }^{16}$ Muhammad Amin Suma, Keadilan Hukum Waris Islam dalam Pendekatan Teks dan Konteks, (Jakarta: Rajawali Pers, 2013), hlm. 83.
} 
Bahwasanya pembagian warisan dengan perbandingan 2:1 yang mana perempuan mendapatkan setengah harta dari laki-laki bukanlah satu- satunya cara pembagian yang terjadi. Akan tetapi hal tersebut hanya salah satu dari berbagai macam pembagian waris. ${ }^{17}$ Perempuan mendapatkan bagian setengah dari laki-laki terjadi apabila ahli waris hanya terdiri dari anak perempuan dan anak laki-laki. Maka jika ada ahli waris lain seperti orangtua, saudara sekandung, kerabat jauh, cucu, kakek, dan lain-lain, pembagian waris pun akan berbeda.

Menurut Al-Qaradhawi, ada dua model orang telah tidak adil terhadap perempuan. Model pertama, model kebarat-baratan yang ingin memaksakan tradisi Barat, yang meliputi dekadensi dan kurang memiliki nilai terutama nilai agama, dan menyimpang dari hal normal, yang cenderung menjauh dari jalan Allah. Sedangkan model kedua termasuk mereka yang memaksa tradisi-tradisi lain pada perempuan, tetapi ini adalah tradisi Timur (bukan tradisi Barat).Tradisi tersebut diberi 'warna' agama. Mereka yang membuat klaim tersebut membuat hal-hal yang ada dari sisi mereka sendiri; berdasarkan apa yang mereka pahami, atau pandangan bahwa mereka dimulai atau dipilih karena sesuai dengan pandangan mereka terhadap perempuan dan tidak menghormati kaum perempuan, agamanya, otaknya atau perilakunya.

Berkaitan dengan hal di atas, bahwa Islam mengakui kesetaraan antara pria dan perempuan di mana Islam memperhatikan hak dan tanggung jawab, dan dalam hal tertentu, terdapat perbedaan, di mana perbedaan itu terkait dengan sifat asal dan fungsi.

\section{Kesimpulan}

Perbandingan antara suami dan istri dengan perbandingan (2:1), apabila suami sebagai satu-satunya orang yang bertanggung jawab ekonomi rumah tangga. Apabila suami bukan sebagai satu-satunya yang bertanggung jawab sebagai pencari nafkah, maka perbandingan ini bisa berubah dalam perspektif gender.

Hukum Waris Islam menetapkan laki-laki dan perempuan sebagai ahli waris terhadap orang tua laki-laki, orang tua perempuan dan terhadap saudaranya. Pembagian untuk anaklaki laki dan anak perempuan sebagian besar mengunakan sistem hukum waris yang berkeadilan gender, antara anak laki-laki dan anak perempuan tidak ada perbedaan antara anak laki-laki maupun anak perempuan mempunyai hakim yang sama kuatnya, pada prinsipnya menganut sistem hukum kewarisan dari (2:1) tetapi dengan pertimbangan, agar berbandingan yang tidak mencolok. Karena jamanya sudah tidak sama dengan awal hukum waris Islam dimana laki-laki sebagai pencari mata pencaharian satu-satunya dalam rumah tangga.

\footnotetext{
${ }^{17}$ Rodiah, dkk, Studi Al-Qur'an Metode dan Konsep, (Yogyakarta: eLSAQ Press, 2010), hlm. 154
} 
eL-Mashlahah, Vol.8, No.2, 2018

\section{DAFTAR PUSTAKA}

\section{Buku}

Amir Syarifuddin, Hukum Kewarisan Islam, Prenada Media, Jakarta, 2004

Abdul Ghofur Anshari, Filsafat Hukum Kewarisan Islam, UII Press, Yogyakarta, 2005

Artijo Alkostar, M Sholeh Amin, Pembangunan Hukum Dalam Perspektif Politik Hukum Nasional, Rajawali Pers, Jakarta, 1986

Ahmad Rofiq, Pembaharuan Hukum Islam di Indonesia, Gama Media, Yogyakarta, 2001

Aristoteles, "The Ethics Of Aristoteles" Dalam S Tasrif,Bunga Rampai Filsafat Hukum, Abardin, Jakarta, 1987

Andre Ata Ulan, Keadilan dan Demokrasi, Telaah Filsafat Politik John Rowls, Kanisius, Yogyakarta, 2001

Bambang Sugiharto, Post Modern Tantangan Bagi Filsafat, Kanisius, Yogyakarta, 1996

Fakih Mansor, Analisis Gender dan Tranformasi Sosial, Pustaka Pelajar, Yogyakarta, 1999

Imam Sudiyat , Asas-Asas Hukum Adat, Bekal Pengantar, Liberty, Yogyakarta, 1982

Taufik Adnan Amal, Islam dan Tantangan Moderenitas, Mizan, Bandung, 1994

Muhammad Amin Suma, Keadilan Hukum Waris Islam dalam Pendekatan Teks dan Konteks, Jakarta: Rajawali Pers, 2013

Notohamijojo, Masalah :Keadilan, Hakikat dan Pengenaannya dalam Bidang Masyarakat, Kebudayaan, Negara dan Antar Negara, Tirta Amerta, Semarang, 1971,

Nurcholis Madjid Islam kemanusiaan dan kemoderenan, Doktrin dan Peradaban, sebuahTelaah Kritis Tentang Masalah Keimaanan, ( Jakarta yayasan Wakaf, Cetakan Ke 2 ,1992

Rodiah, dkk, Studi Al-Qur'an Metode dan Konsep, (Yogyakarta: eLSAQ Press, 2010

Suhardi K Lubis, Komis Simanjuntak, Hukum Waris Islam Lengkap dan Praktis, Sinar Grafika, Jakarta, 1995,

Qurtubi Al Sumanto ,Era baru Figih Indonesia hlm 5 Yogyakarta Cermin 1999. 